\title{
METHODOLOGY FOR GREEN AND BUILT VOLUME ANALYSIS
}

\author{
SENA, Italo Sousa de; ${ }^{\text {* }}$ CASAGRANDE, Pedro Benedito; ${ }^{b}$ ROCHA, Nicole Andrade; ${ }^{c}$
}

FONSECA, Bráulio Magalhães; ${ }^{\mathrm{d}}$ MOURA, Ana Clara Mourão; ${ }^{\mathrm{e}}$

(a) PhD candidate in Geography. Federal University of Minas Gerais (UFMG), Belo Horizonte (MG), Brazil. ORCID ID: https://orcid.org/00000002-6500-5609. CURRICULUM LATTES: http://lattes.cnpq.br/4445767615772667

(b) $\mathrm{PhD}$ candidate in Geology. Federal University of Minas Gerais (UFMG), Belo Horizonte (MG), Brazil. ORCID ID: https://orcid.org/00000003-4515-1630. CURRICULUM LATTES: http://lattes.cnpq.br/6024374437993139

(c) PhD candidate in Architecture and Urbanism. Federal University of Minas Gerais (UFMG), Belo Horizonte (MG), Brazil. ORCID ID: https:// orcid.org/0000-0001-6902-9344. CURRICULUM LATTES: http://lattes.cnpq.br/8339258664325884

(d) PhD in Geography. Professor at Federal University of Minas Gerais (UFMG), Belo Horizonte (MG), Brazil. ORCID ID: https://orcid.org/00000002-2282-8568. CURRICULUM LATTES: http://lattes.cnpq.br/8551916275030169

(e) PhD in Geography. Professor at Federal University of Minas Gerais (UFMG), Belo Horizonte (MG), Brazil. ORCID ID: https://orcid.org/00000001-6823-1938. CURRICULUM LATTES: http://lattes.cnpq.br/6448889980942931

(*) CORRESPONDING AUTHOR

Address: LabgeoproEA/UFMG - Rua Paraíba, 697, Sala 410A - Savassi, CEP: 30130-140 - Belo Horizonte (MG), Brasil. Tel. (+55 31$) 34098827$. E-mail: italosena@ufmg.br

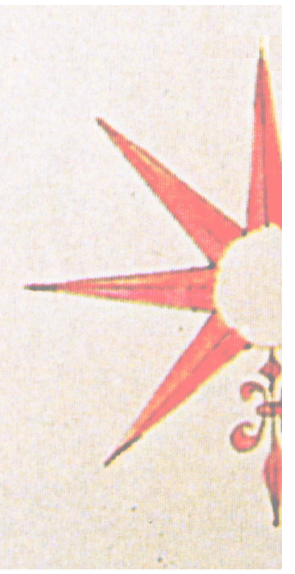

\begin{abstract}
Today, in some Brazilian cities, there is the possibility of using high-resolution data and automated classification based on spectral bands. Thus, this article aims to evaluate the association of the NDVI(normalized difference vegetation index) to the use of LiDAR, in order to analyze urban vegetation cover and the changes of the local landscapes. It was observed that the association of the high spatial resolution of an aerophotogrammetric image to the spectral response in the near infrared range allowed the vegetation to be identified. This enabled the documentation, visualization and analysis of a location's phenomenon, facilitating the investigation of spatial relationships through representation by maps, charts, especially for simulating possible spatial scenarios and thus permitting the evaluation of interventions and predictions to be made, assisting projects or proposed laws and urban parameters.
\end{abstract}

Keywords: LIDAR; NDVI; Remote sensing; Green areas; Urban management; Pampulha.

\section{RESUMO / RESUME}

\section{METODOLOGIA PARA ANÁLISE DO VOLUME VEGETACIONAL E CONSTRUÍDO}

Hoje, em algumas cidades brasileiras, apresenta-se possibilidade de utilização de dados de alta resolução e de classificação automatizada baseada em bandas espectrais.Assim, este artigo tem por objetivo avaliar a associação do índice espectral NDVI (NormalizedDifferenceVegetation Index) ao uso do LiDAR, visando analisar a cobertura vegetal urbana e as transformações de suas paisagens.Observou-se que a associação da alta resolução espacial de uma imagem aerofotogramétrica à resposta espectral na faixa do infravermelho próximo permitiu a identificação otimizada da cobertura vegetal arbórea. Viabilizando a documentação, visualização e análise dos fenômenos do lugar, facilitando a investigação das relações espaciais, através da representação por mapas, gráficos eprincipalmente para simulação de possíveis cenários espaciais, além disso, possibilitou avaliar intervenções e realizar previsões, auxiliando projeto ou proposta de leis e parâmetros urbanísticos.

Palavras chaves: LIDAR; NDVI;Uso remoto;Áreas verdes;Gestão urbana; Pampulha.

\section{MÉTHODOLOGIE POUR L’ANALYSE DU VOLUME VÉGÉTATIF ET CONSTRUIT}

Aujourd'hui, dans certaines villes brésiliennes, il y a la possibilité d'utiliser une des données de haute résolution et de la classification automatisée basée sur des bandes spectrales. Ainsi, cet article vise évaluer l'association de l'indice spectral NDVI (Normalized Indice de végétation par différence) pour l'utilisation de LiDAR afin d'analyser la végétation urbaine et les changements des paysages locaux. Il a été observé que l'association d'une image aérophotogramétrique de haute résolution à la réponse spectrale du niveau d' infrarouge permet l'identification de la végétation. Cela a permis la documentation, la visualisation et analyse d'un phénomène de location, ce qui facilite l'investigation des telations spatiales par le biais d'unr représentation des cartes, des graphiques, surtout pour la simulation des probables scénarios spatiaux, d'où l'évaluation des interventions et prévisions à accomplir, en soutenant les projets ou les lois proposées ainsi que les paramètres urbains.

Mots Cles: LIDAR; NDVI; Télédétection; Espaces verts; Gestion urbaine; Pampulha. 


\section{INTRODUCTION}

The use of remote sensing for studies of vegetation coverage using sources of information in high spatial resolution is not something new, since the use of aerophotogrammetric data and laser scanners are already an affordable reality. However, there are few studies that approach three-dimensional studies applied to urban vegetation cover, principally using LiDAR (Light Detection and Ranging) associated with the NDVI (Normalized Difference Vegetation Index) (JENSEN, 2007; GIONGO et al. 2010), in order to support the comparison between built and vegetation volumes to evaluate urban environmental quality. The application of LiDAR associated with NDVI in urban land allows a new way of thinking about urban space that seeks to guarantee the quality of people's environment and life, especially with regard to the vegetation cover in the urban landscape, in order to consider the importance of this variable in landscapes that are increasingly impacted by the processes of intense anthropization.

Dupagne, A. and Hégron, G. (2002) treat the urban environment as a concept that encompasses the domain of urban design, arising from the perception of the observer and participants in the interpretation of the interactions between natural phenomena, urban activities and the urban form. Thus, factors such as thermal comfort, sound, ambient light and microclimate tend to have a great influence on the preferences of the people in an urban area. Mascaró and Mascaró (2009) reinforce that the relationship between green urban areas and the built environment favors the quality of the urban environment, besides contributing to the identification and aesthetics of a place. The present article adopts a concept of urban ambience related to the essence of the landscape of a place, seeking an environmental balance in relation to the good and the appropriation of urban space by the people who use it.

The arboreal vegetation in an urban environment has different functions, related to aesthetic quality, the creation of possibilities for socialization and leisure, the protection of biodiversity, the protection against geotechnical problems, the protection of the replenishing of aquifers and springs, and also to ensure the maintenance of the environmental equilibrium related to the climate, the humidity of the environment, air quality and acoustic control (LOBODA et al., 2005; ANTHROP, 2004; BESSA, SOARES, 2003; HOUGHTON, 1994; SANTOS, 1994).

One example is the research technique that maps urban green areas using LiDAR technology, as used in a study by Rafiee et al. (2016), in which the authors evaluated the local impact of the volume of trees on the heat island phenomenon at night in the city of Amsterdam, Holland. There are also studies that explore LiDAR as a source of information on built volumes, as in the case of Thomas et al. (2016), who associated the built volume with population estimates. Other studies include Souza and Amorim, (2012) who explore the importance of this type of data capture in the construction of a 3D register, the basis for territorial management.

The differential of the present study is that deals, simultaneously, with volumetric data for vegetation and building cover, in order to favor studies on urban ambience. In this manner, this paper's objective is to estimate the volume of urban green areas and buildings from LiDAR data, distinguishing the robust vegetation cover highlighted by the normalized index of vegetation cover, with a view to contribute to studies of the balance of systems in the Pampulha region, in Belo Horizonte, Brazil, an area that has recently been awarded the World Heritage title by UNESCO and needs to adopt measures to characterize, maintain and improve the quality of the natural and anthropic landscape.

\section{USE OF LIDAR AND NDVI}

LiDAR technology (Light Detection and Ranging) has added new uses and possibilities of spatial surveys to studies of the terrestrial surface. It is based on the active sensing technique, 
demonstrating an excellent ability to acquire information in short time intervals through the use of lasers, in order to obtain clouds of three-dimensional points containing $\mathrm{X}, \mathrm{Y}, \mathrm{Z}$ coordinates, as well as the intensity of the reflection, echo number (return) and others. Initially, the applications were more directed to the creation of the Digital Terrain Model (DTM), and Digital Surface Model (DSM), favoring the modeling of any rugosity existing on the terrestrial surface, such as buildings and treetops. (GIONGO et al. 2010; RIBAS et al., 2014).

The NDVI (Normalized Difference Vegetation Index) is based on the spectral signature of the behavior of vegetation cover targets, which have specific responses related to photosynthesis, the process that absorbs solar radiation in the red region. Plant cells reflect strongly in the near infrared region. The portions absorbed by the red and reflected in the infrared vary according to the condition of the plants. These can be associated with other normalized indexes to make correlations and verify the ambience of the study location and so allow a better management of the place (ROUSE et. al., 1973; MYNENI, 1995; FREIRE, PACHECO, 2005).

Nowadays, in some Brazilian cities that have the resources to invest in data, it is possible to use high spatial resolution data (up to 20 centimeters) and automated classification based on spectral bands (such as the possibility of working with infrared band on satellite images or images from aerial photogrammetric flights). This new possibility implies an improvement in the information that can help in the proposal of urban parameters, such as: impermeability rates, infiltration rates, heat zones, warming, environmental comfort, soil use, soil cover variability index, among others.

\section{CASE STUDY}

With the objective of demonstrating the potential and limitations of the application of studies using high resolution images in Brazil, this work focuses on the Pampulha Region, in Belo Horizonte. It was chosen as a case study, since it is a region that is still significantly favored with vegetation cover, but it is at risk of transformation due to the growth of the city and the promotion of the lakeside and the its features. It has been designated a UNESCO World Heritage Site, due to its importance to Brazilian modernist architecture, designed by Oscar Niemeyer and with contributions from Portinari, Burle Marx, Ceschiatti and Paulo Werneck (CARSALADE, 2015). The title favors the interest in the transformation of land use and occupation, which, if not well orchestrated, may have the consequence of suppressing existing qualities.

However, the same logic of evaluating and comparing vegetation and constructed volume can be applied in other urban studies in Brazil, so this article is a methodological contribution that provides the basis for the proposal of urban parameters to be inserted in Master Plans, helping to maintain the quality of urban life.

Due to its environmental characteristics (gentle relief and declivity) and its cultural importance, Pampulha has become well-known in Belo Horizonte (Brazil), attracting private investors and professionals from the real estate market, resulting in a dynamic conformation and an ongoing process of transformation of the landscape (CARSALADE and CASTRO, 2011). It is an area of conflicts of interest regarding the protection of cultural patrimony, expansion by densification or urban spreading and the expressive presence of vegetation.

\section{METHODOLOGY}

The methodological process followed four main steps, starting with the organization of the database, followed by the pre-processing and processing of the refined data and, finally, the analysis of the results obtained.

The initial data were kindly provided by PBH / Prodabel (Belo Horizonte City Hall). The collection was composed of clouds of points from LiDAR (Light Detection and Ranging) separa- 
ted into information about DTM (Digital Terrain Model) and DSM (Digital Surface Model), with cadastral data on roads, blocks, lots and projections of buildings, and by high resolution aerial photogrammetric survey images that included both visible and near infrared bands.

The conversion of the data from the *.LAS file to shapefile used the ArcGIS 3D Analyst tool package. Data Management Tools was used to convert the cloud of points created to single points (Multipart to Singlepart) and, finally, 3D Analyst carried out the addition of the $\mathrm{Z}$ attribute through the Add Z Information.

The two-dimensional projection of the arboreal vegetation fragments was extracted using the NDVI (Normalized Digital Vegetation Index). The Infrared Near and Red bands were used in the calculation of the NDVI by rasters, and then transformed into vector polygons. The calculation of NDVI followed the formula (1):

$$
N D V I=\frac{(p i v p-p v)}{(p i v p+p v)}
$$

At where pivp is near infrared and pv is red.

With the vector data of arboreal vegetation fragments and building projections it was possible to calculate the volume of the forms from the projected area in top view, and the height $(\mathrm{Z})$ extracted from the three-dimensional point cloud (Figure 1). The data were spatialized in 2D and 3D form (Figure 2). For the two-dimensional representation, a thematic map was created, showing the volume of the analyzed forms, whereas the ArcScene / ArcGIS application was used for the three-dimensional visualization.

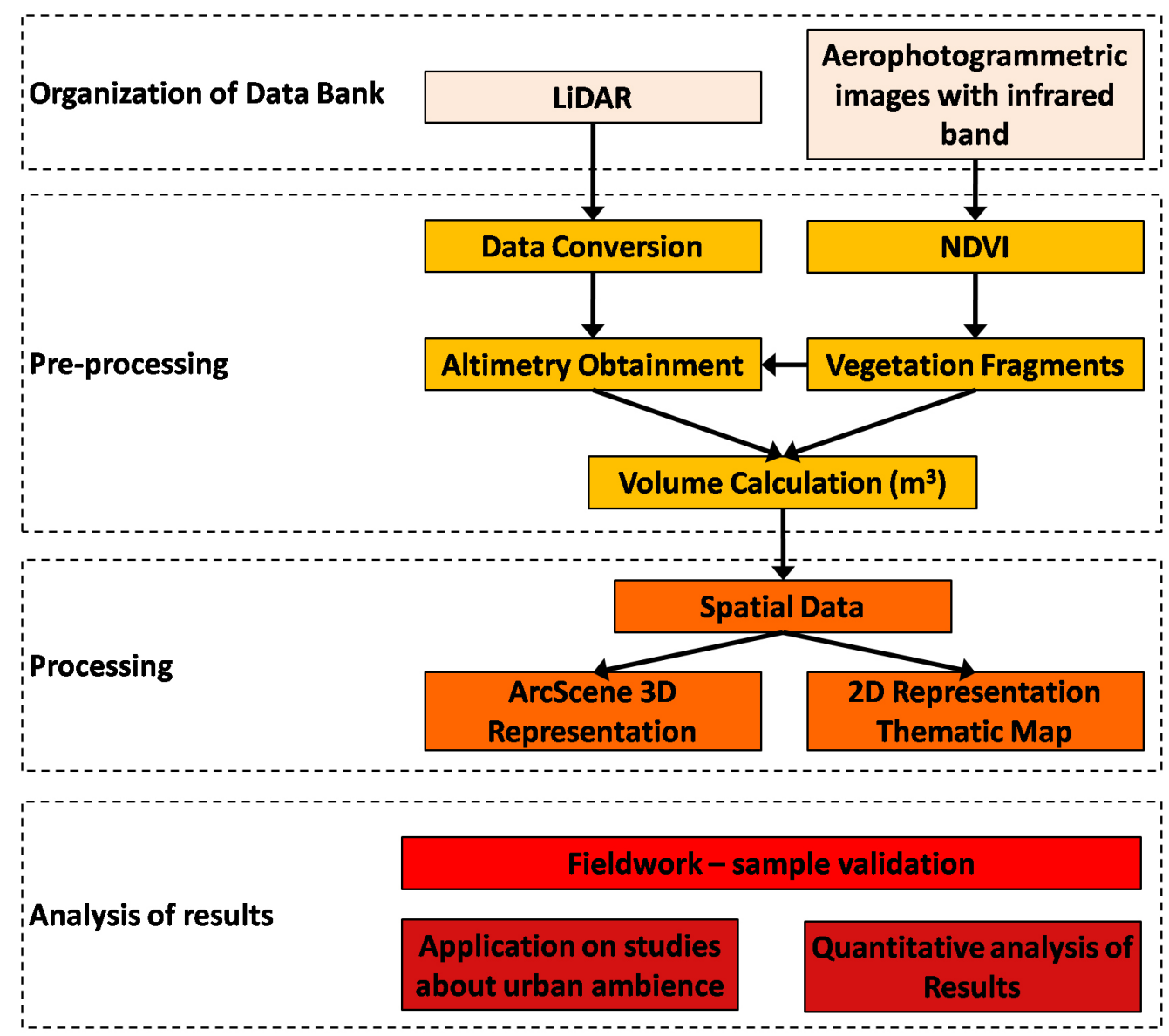

Figure 1 - Methodological Flowchart 

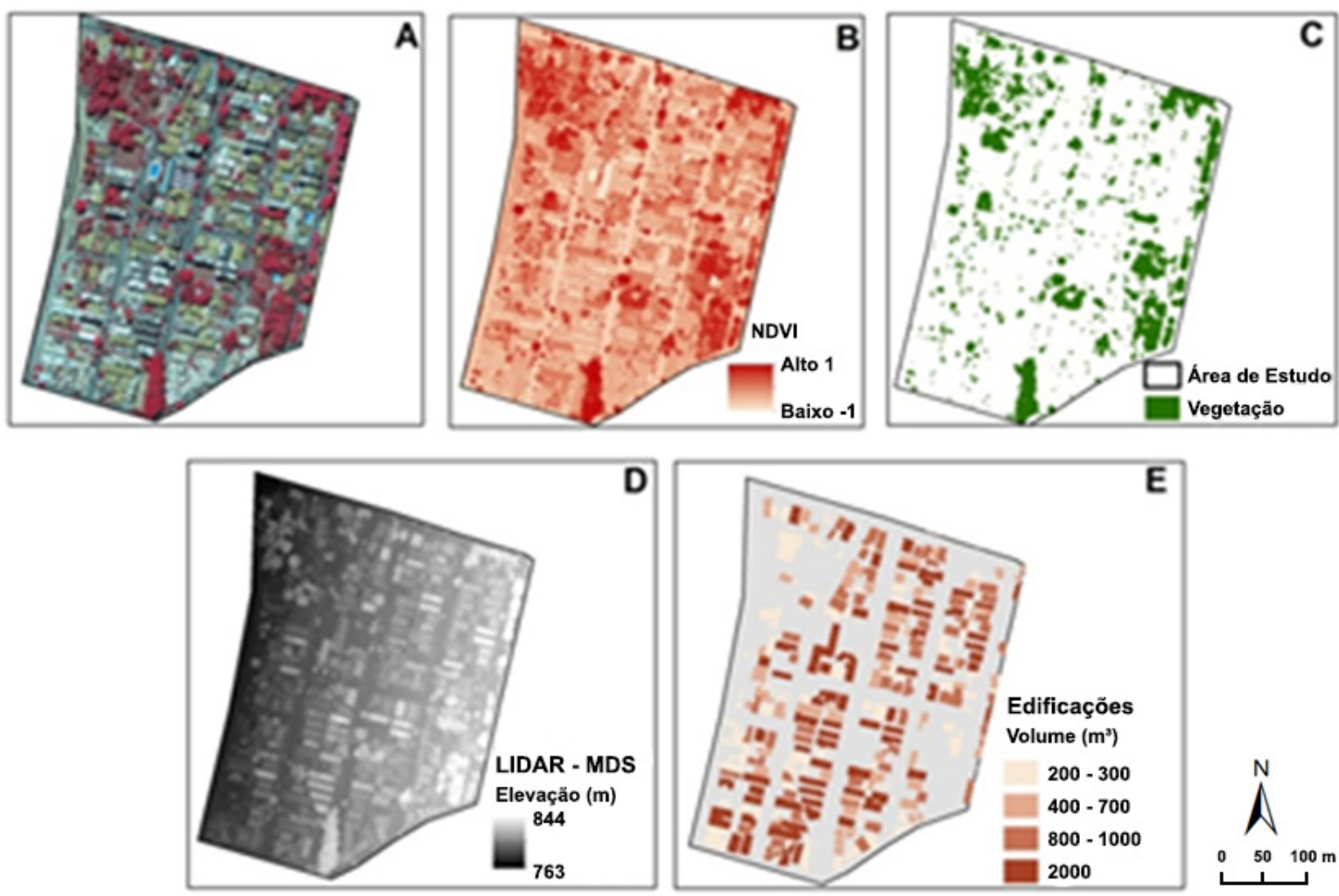

E

Figure 2 - A) High resolution image; B) NDVI; C) Tree vegetation; D) Elevation; E) Built volume.

Field work was carried out to validate the results, with visual verification and a photographic survey of the study area. The four sites that had the largest areas of arboreal vegetation were visited. The objective of the photographic survey was to document the spatial reality of the study area, with the purpose of highlighting the particularities of each validation site. From the delimitation of the validation sites, statistical analyzes of the volumes of buildings and vegetation were carried out. The standard deviation of the samples was analyzed in order to evaluate the spacing of the data in relation to the mean of the samples. The calculation of the standard deviation can be expressed from equation (2):

$$
\operatorname{STD}=\sqrt{\frac{\sum\left(x_{i}-\bar{x}\right)^{2}}{n}}
$$

Where $\mathrm{x}$ i corresponds to the value of the sample, $\mathrm{x}^{-}$corresponds to the mean values of the samples and $\mathrm{n}$ to the number of samples.

\section{PARTIAL AND FINAL RESULTS OBTAINED}

The association of LiDAR to NDVI allowed the optimized identification of arboreal vegetation cover, mainly in the three-dimensional representation, indicating new possible applications to studies of the urban environment. The first process in the use of aerophotogrammetric images was to explore the possible combinations of the stands, which could be treated as false-color (blue, red and near infrared bands) and true color (RGB bands in the visible range). From the different combinations of bands, the potential of the use of the infrared band was confirmed, since vegetation had high reflectance in this band, with a high spectral response. On the other hand, the RGB composition in 
the visible range favors the association with the existing reality. (Figure 3).

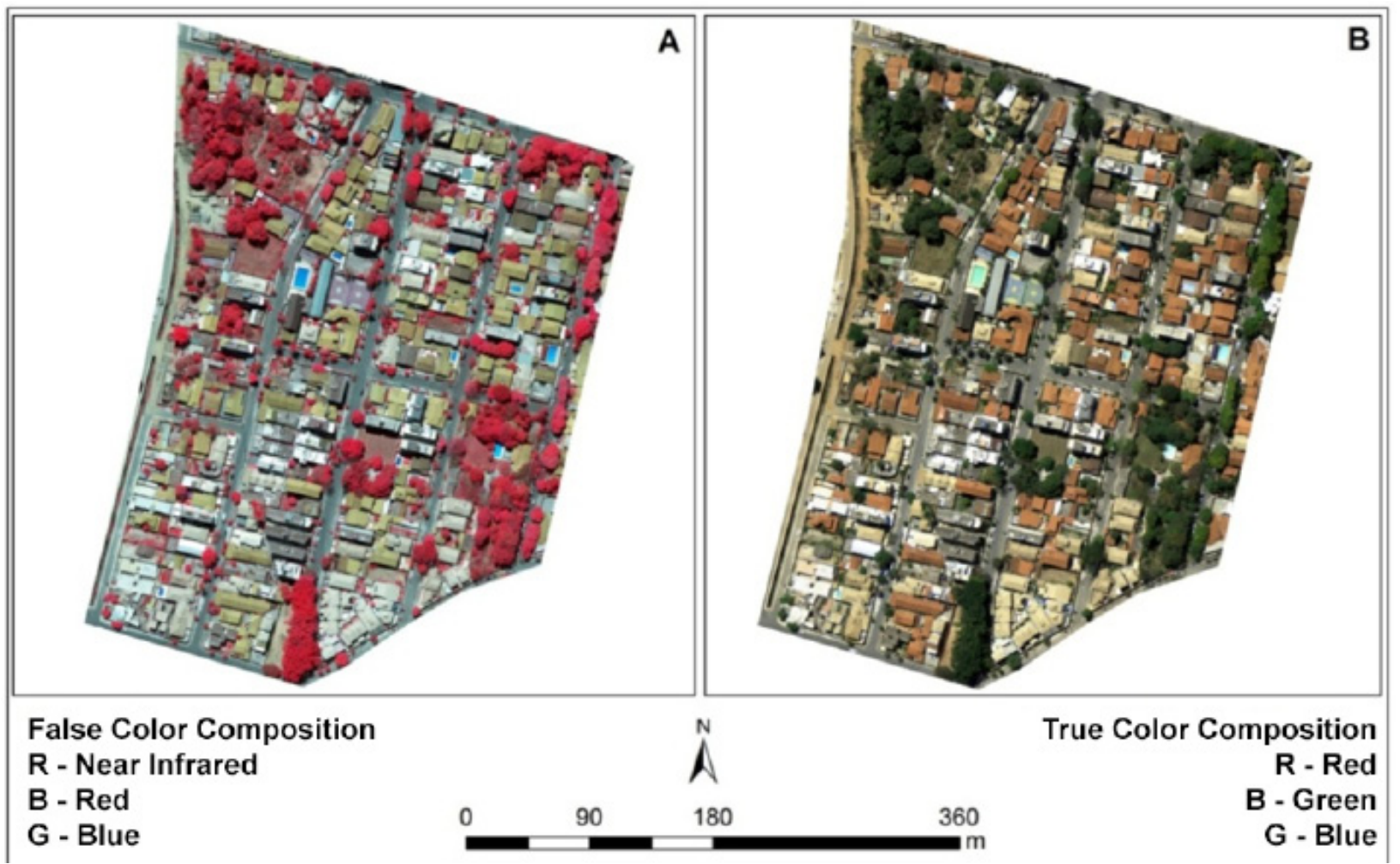

Figure 3 - A) False color composition; B) True color composition.

The next step was the extraction of the NDVI of the infrared bands (Figure 4, detail A) and Red (Figure 5, detail B) using rasters, resulting in the presence index of vegetation (Figure 4, detail C).

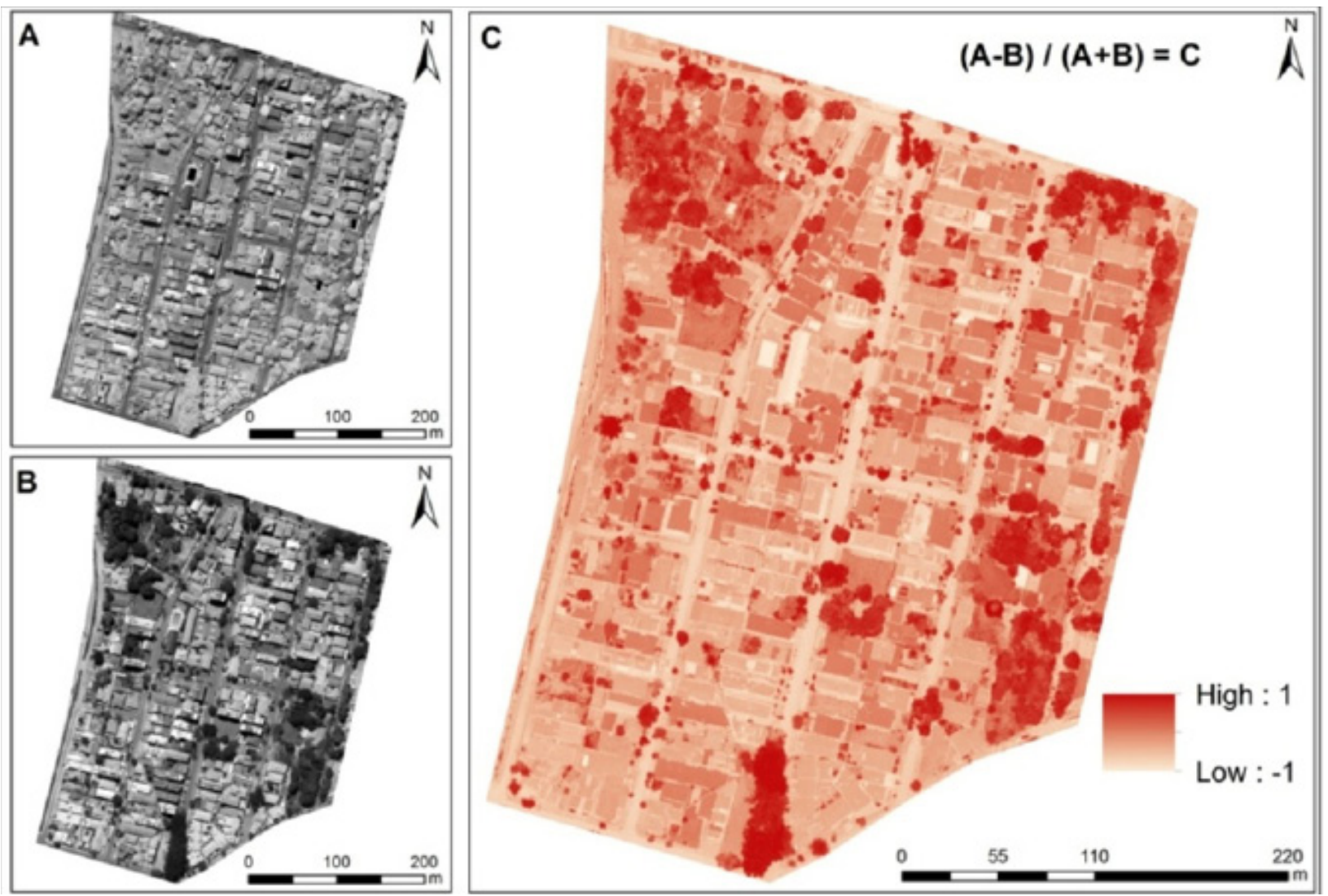

Figure 4 - A) Image representing the near infrared band; B) Image representing the red band; C) NDVI. 
The vegetation presence / robustness index, represented by the NDVI (Figure 5A) was then segmented to highlight its distribution in values, divided into classes ranging from "Absence of Vegetation" in shades of purple and "Robust Vegetation" in shades of green (Figure 5B). The NDVI can range from -1 to 1 , with responses greater than 0.16 to extract vegetation fragments (Figure 6C).

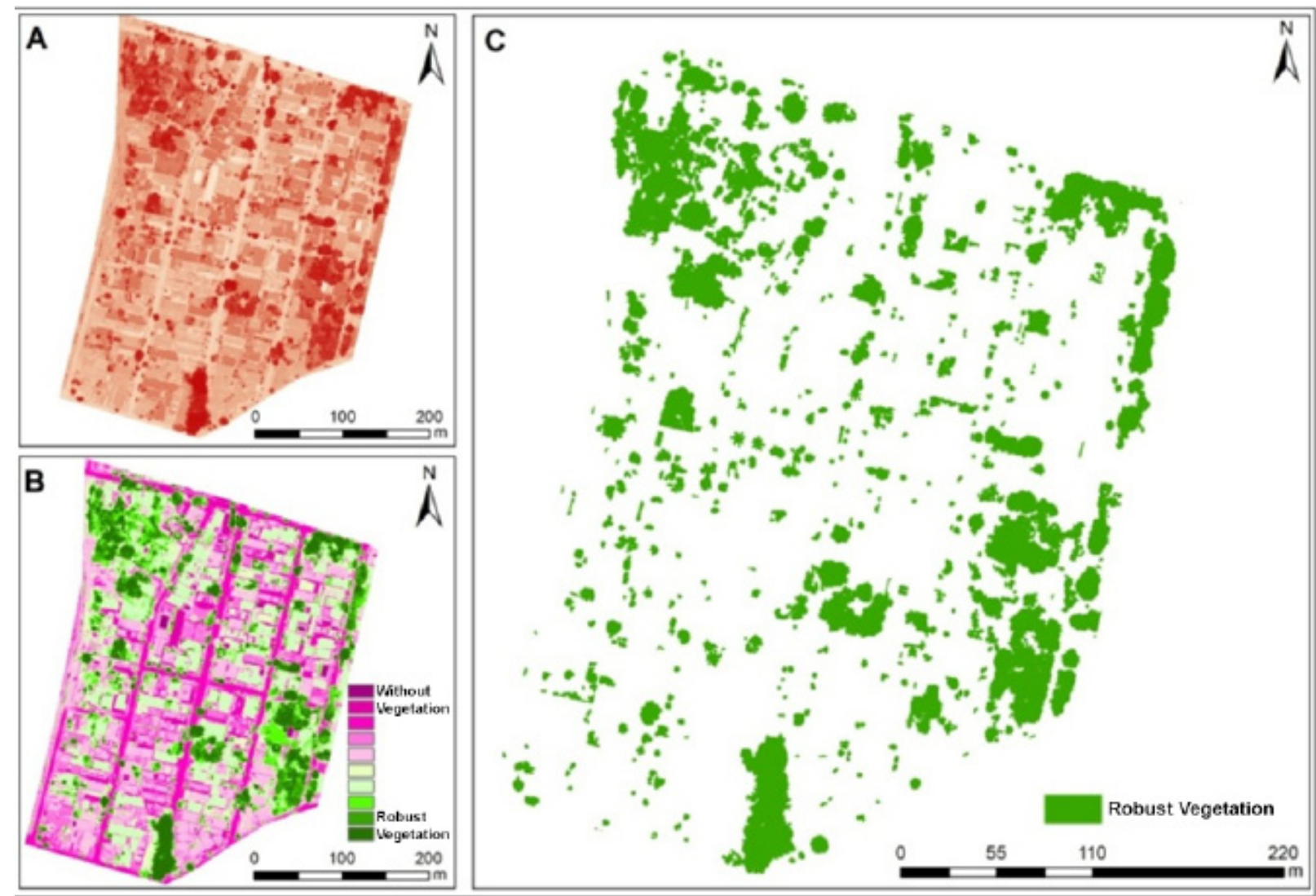

Figure 5 - A) NDVI; B) NDVI slice, rose without vegetation and green with vegetation; C) Fragments of robust vegetation.

In addition to the vegetation cover studies, the conditions of the built volumes were mapped and analyzed. The work was performed from the LiDAR points cloud (Figure 6A). The information was separated into DSM (Digital Surface Model) and DTM (Digital Terrain Model) and it was possible to put together the topographic reality of the area, lower to the west due to the fluvial plain of a stream that runs north-south, and to the east an elevation of the terrain (Figure 6B). From the cadastral data of building projections, the heights were extracted and specialized volumes were constructed (Figure 6C).

The data collected for the vegetation fragments were also composed in order to produce projection polygons for which points with altimetry data were extracted, which favored the composition of a TIN (Triangular Network) three-dimensional mesh (Figure 7A and 7B). From the three-dimensional elements composed of vegetation fragments, vegetation volumes were calculated, classified by their dimensions (Figure 7C). 


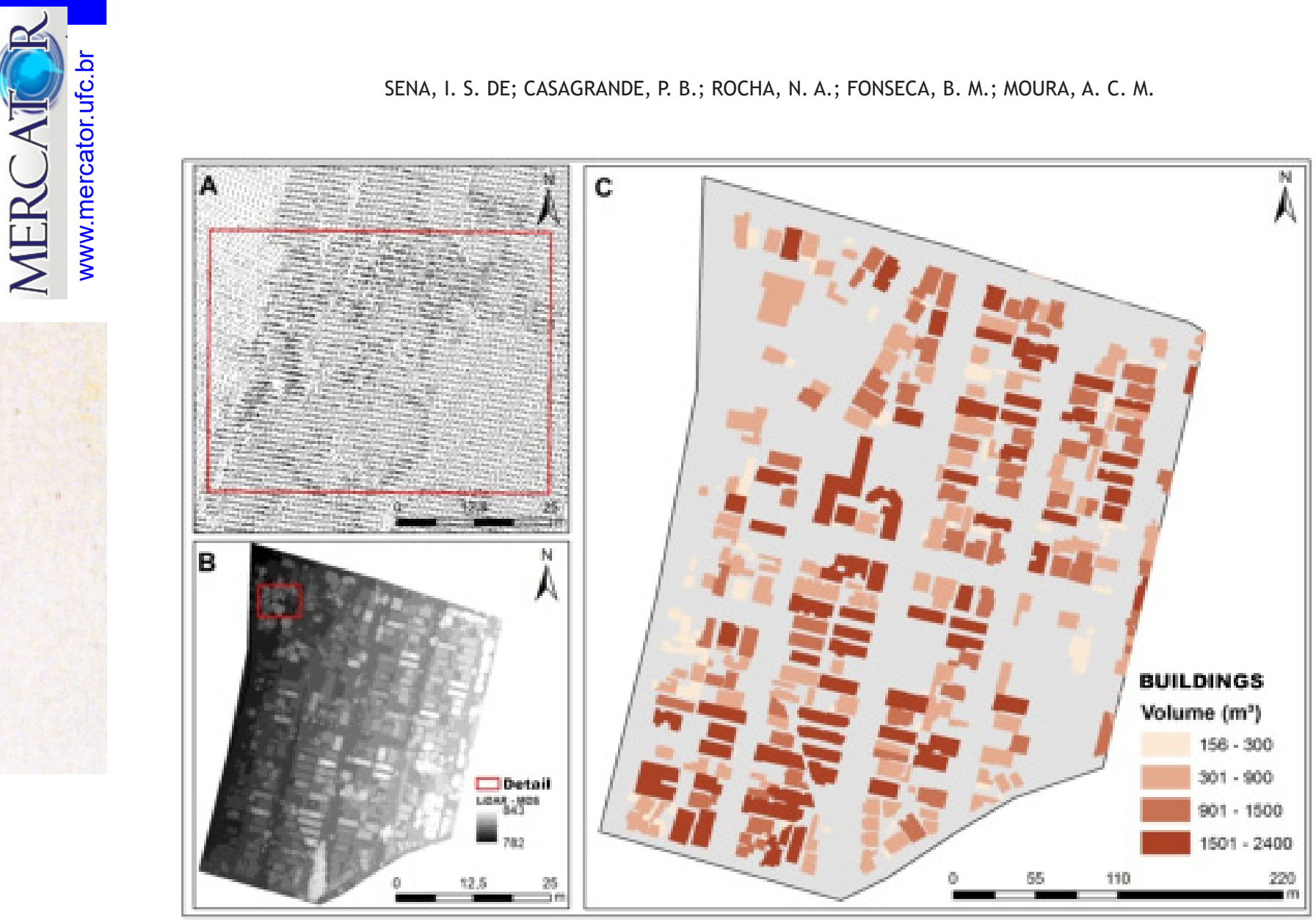

Figure 6 - A) Point cloud; B) Digital Surface Model (MDS); C) Volumetric model of buildings.

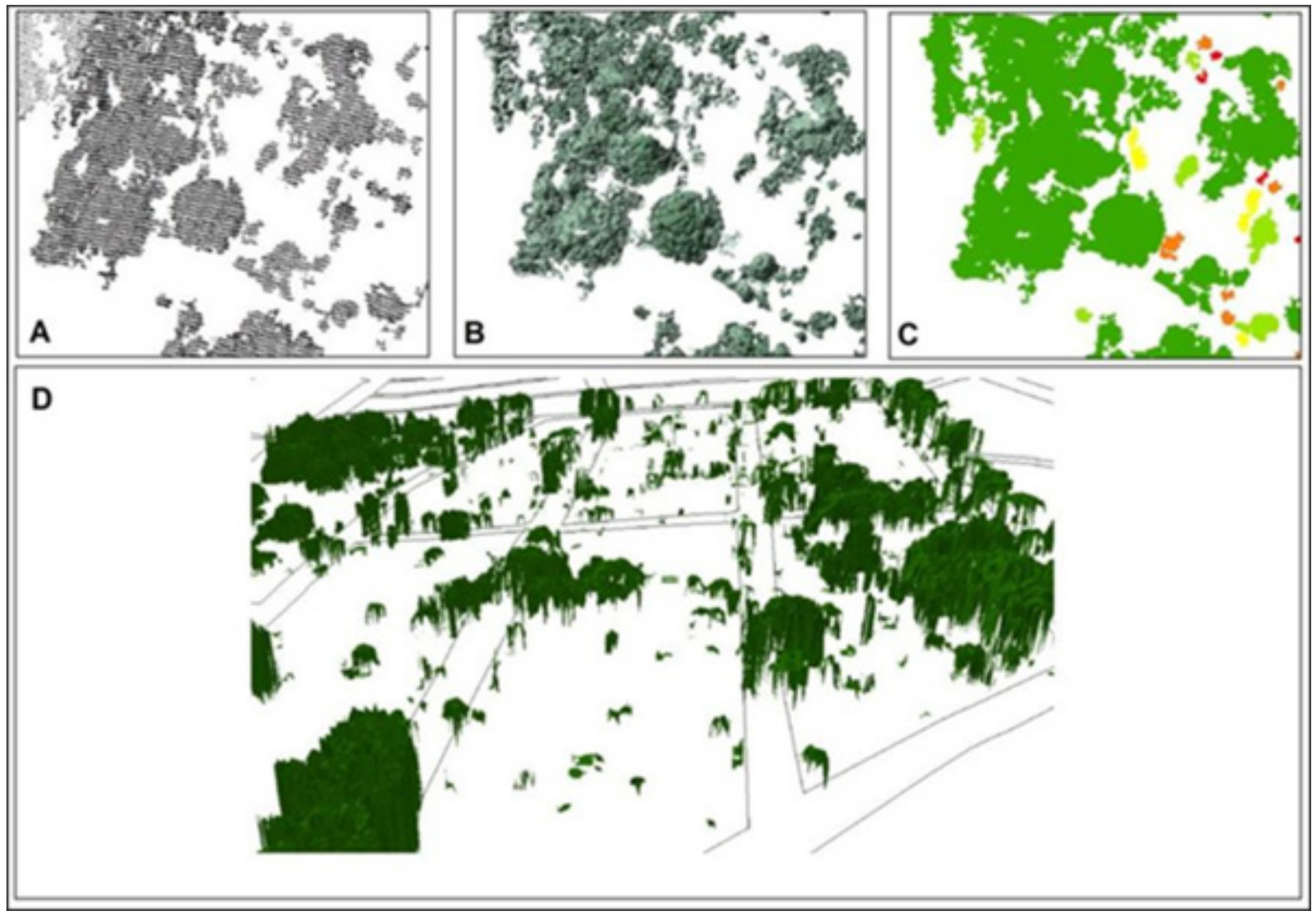

Figure 7 - A) Point cloud; B) TIN (Triangulated Irregular Network), highlighting the large vegetation; C) Calculation of the volumes of fragments of vegetation; D) 3D visualization of the vegetative fragments. 
Four areas were chosen to validate the methodological process, among those that presented greater volume of vegetation cover and an expressive volume of buildings. The vegetation volumes (green tones in Figure 8) and buildings (red tones in Figure 8) were observed. The areas were visited in order to carry out a material photographic survey and visual inspection of the results found during the lab work stage (Figure 9).

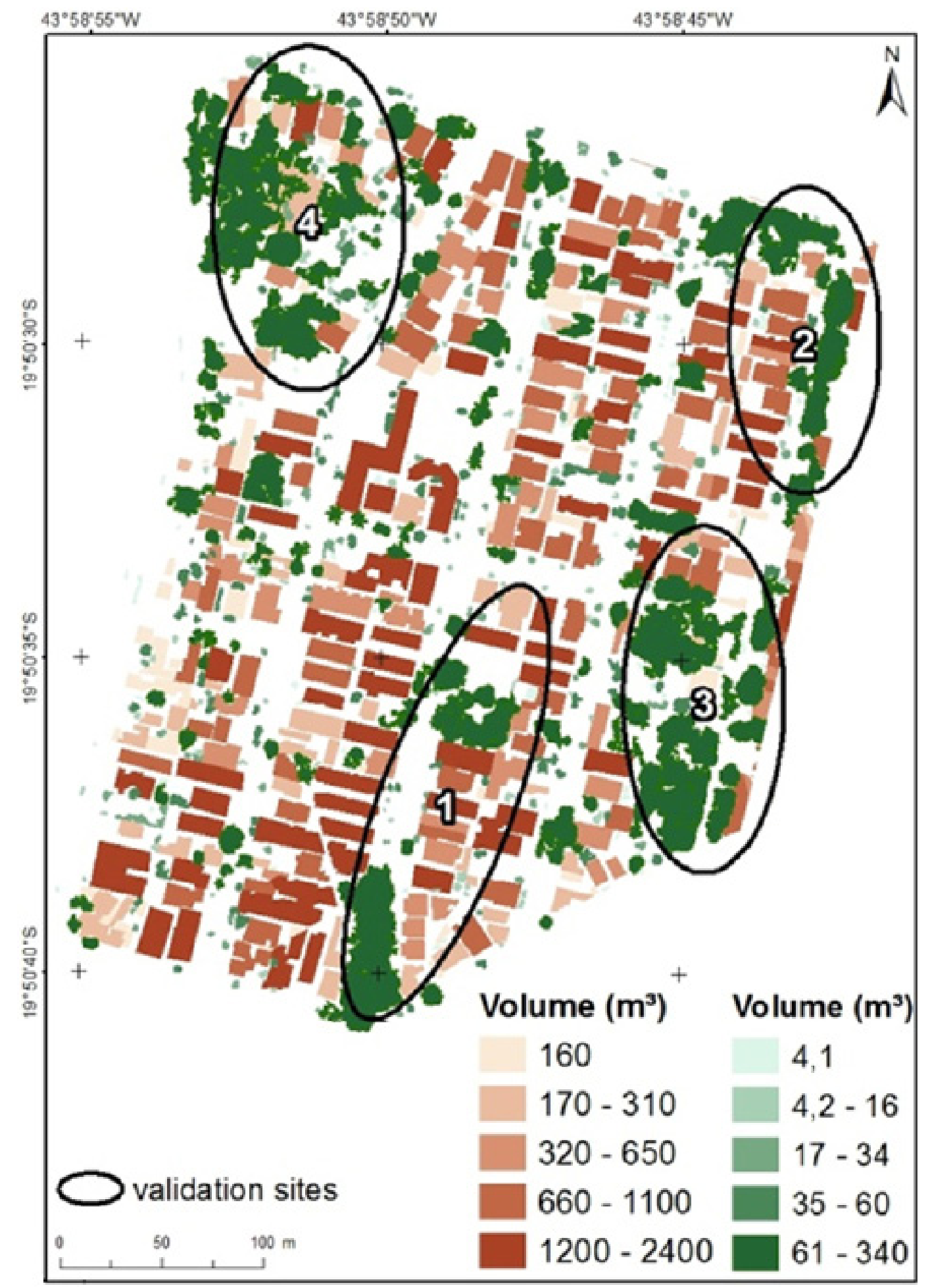

Figure 8 - Result of LiDAR associated with NDVI. In shades of green the volumes of vegetation expressive and in shades of red the volumes of buildings. 


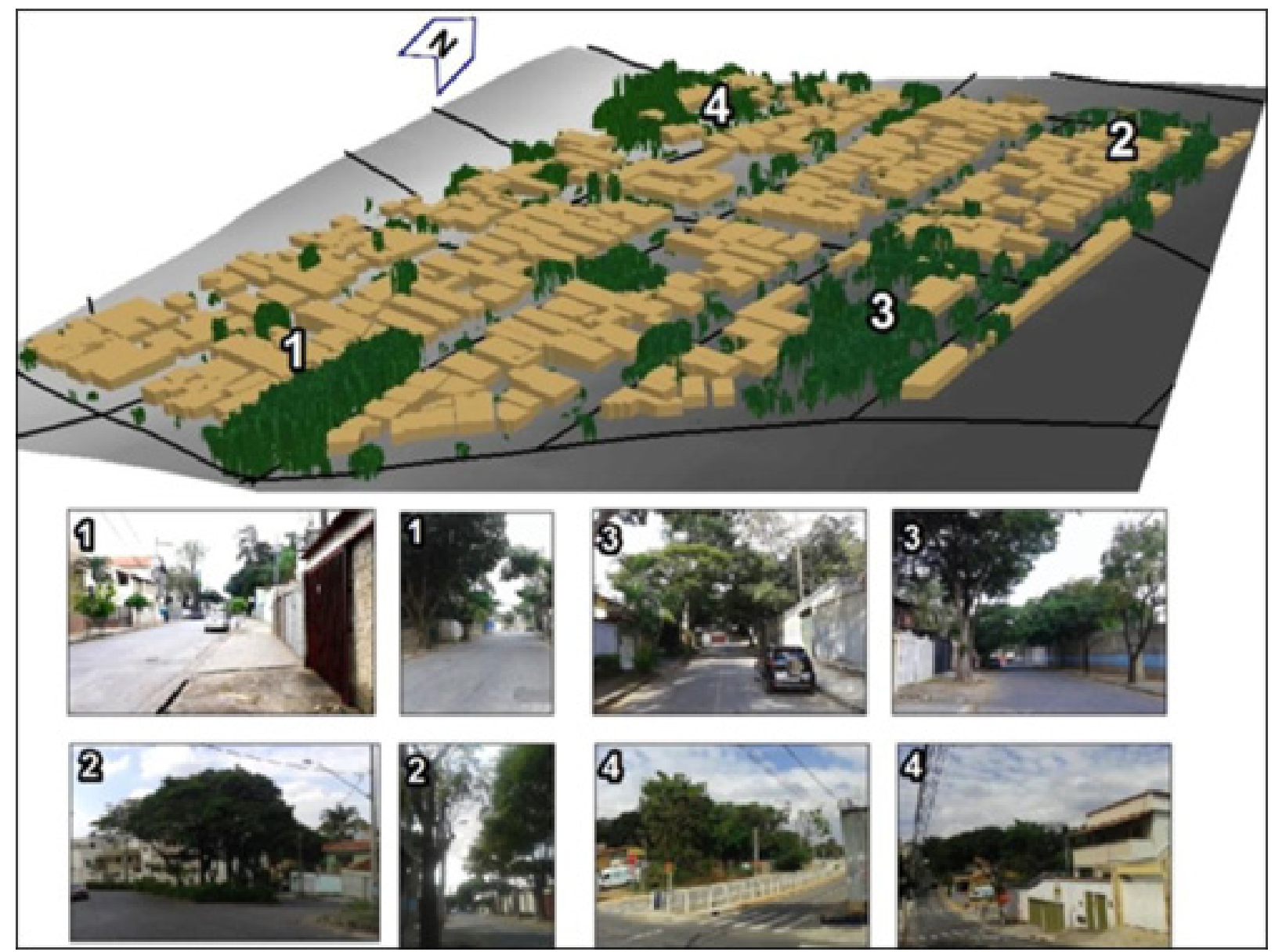

Figure 9 - 3D model and photographs of the study areas.

After the selection of the validation areas, the standard deviation of the volumes of building and expressive arboreal vegetation was calculated, which allowed the two variables to be related in a quantitative way, and not only by visual inspection, favoring the comparison between the variation in the vegetation volume in relation to the variation in the built volume.

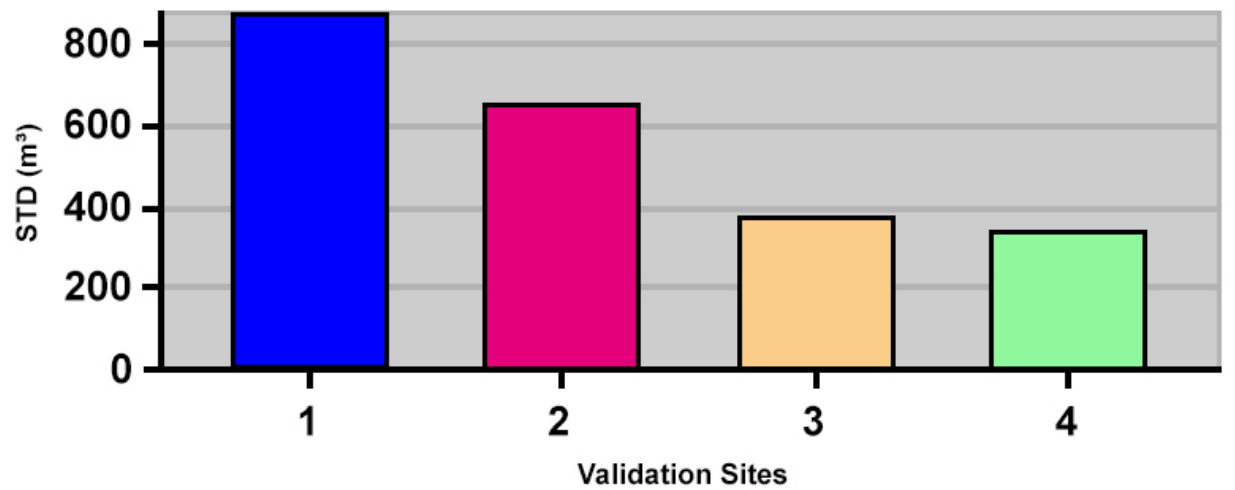

Figure 10 - Standard deviation between built volumes by validation area.

The graph in Figure 11 shows that the validation sample area number 1 had the largest variation of the standard deviation (Standard Deviation - STD) for built volume, indicating that this sample area is quite heterogeneous regarding the occupation typologies of the lots. In this area there are both small and large buildings, which is indicative of a greater transformation dynamic and potential for alterations, resulting from possibilities allowed by land use legislation. The most 
homogeneous areas among those selected are 3 and 4, in which the standard deviation of the built volume tends towards the low and the volumes themselves are also smaller. This pattern refers to conditions in more stable areas that should be observed because they still have volumetric stock for new construction and alterations. The transformation dynamic of in these places is still low, but there are conditions that may favor changes of inventory to larger volumes, so it is necessary to discuss what would be the expected landscape for the location.

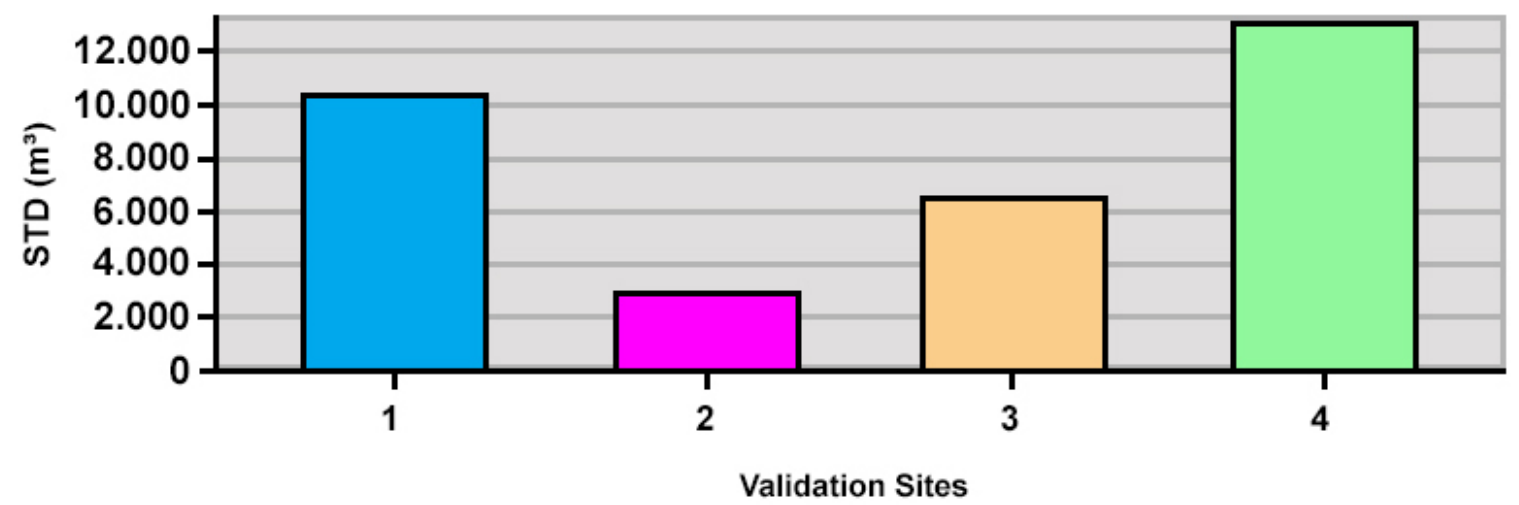

Figure 11 - Standard Deviation of the Volumes of Vegetation Fragments

In Figure 12, which analyzes the variation of the STD for vegetation volumes, the ratio of the vegetation volume was analyzed. Comparing the values obtained with the standard deviation of the constructed volumes, it is observed that the variability of vegetation conditions is much greater. The heterogeneity of the vegetation volume in the study areas is evident. In area 4 there is a more expressive volume of vegetation in relation to the other areas, but the great variability of conditions among the existing vegetation fragments is evident. In area 2 there is more built volume, $\mathrm{m} /$ uch variability between these constructed volumes, and less expression in the vegetation volumes.

\section{FINAL CONSIDERATIONS}

The comparison between the volumes of buildings and vegetation fragments, as well as the study of the variability of constructed volumes performed herein, as well as the identification of notable spaces from the point of view of environmental quality are important for urban planning. Actions such as the authorization of instruments of volumetric negotiation in urban land use may consider the transformation capacity of an area according to the volumetric balance of landscapes. These instruments include the OODC (Onerous Right to Grant Construction), TDC (Right of Building Transfer) and OUC (Consortia of Urban Operations) that are the result of the logic of created land (BRASIL, 2001).

Methodologies of information production, the promotion of visualization and calculation of values to reach reference values and indexes can assist in the preservation of notable landscapes and environmentally important areas, or even place negotiation conditions as mitigating principles for urban transformation. For example, it is possible to propose new parameters for volumetric vegetation rates, soil permeability rates, or other factors that result in the maintenance or amplification of environmental improvements. These can be applied on any territorial scale, plot, lot, block or the urban area. Therefore, it is possible to institute an expected volume for vegetation for any territorial unit, and to act in such a way that in the individual unit this interest results in the protection of a volume of vegetation fragment. The City Statute, Law 10.257 / 2001 (BRAZIL, 2001), makes clear property is private, but its use must fulfill a social interest. This definition authorizes actions on the individual scale (lot) in the sum of individual properties (in the block or zone), so that the end use and parameters applied fulfill a collective interest. This means that if it is observed that it in 
the community's interest to maintain some conditions of the use of a lot, for example, vegetation volumetry, this can be interpreted as being of social interest.

It is an important action of urban management to evaluate the possibilities and attractiveness for the construction of new buildings, either in vacant lots or by increasing the built volume or by replacing old buildings of smaller volumes for larger buildings. Processes that simulate and interpret this potential can favor the discussion about where there are risks of transformation and where the landscape deserves to be maintained to reflect collective values. It should be noted that for Lynch (1960) in the work "The image of the city" the author defends the importance of the role of the urban landscape in the everyday city. He writes: "Among its many roles, the urban landscape is also something to be seen and remembered, a set of elements that we hope will give us pleasure."

The advantages of afforestation for the city are known, since it is responsible for aesthetics, which helps add value and in the identification of the place; it provides socialization and leisure, through parks and gardens; it protects local biodiversity and the reserves of water sources, responsible for the city's water supply; and the maintenance of the environmental balance related to climate, ambient humidity, air quality and acoustic control (LOBODA et al., 2005).

Green areas are an inseparable part of the landscape that makes up the city, responsible for sensations, feelings and memories, elements understood as essential and that characterize the identity of a place - genius-loci - "in a broad degree of significance and coherence ..." Benevolo (2004, p.141), where each specimen taken away or inserted without adequate study compromises the unity of the whole.

Finally, the topographic data from the LiDAR technology, associated with digital aerial photogrammetry data with information about the infrared band allows calculations to identify the robustness of the vegetation, favor the analysis of the volumetrics and the comparison of vegetation fragments and built areas. The objective is the integrated analysis of these aspects, favoring the visualization and analysis of urban environmental conditions, in order to support decisions about urban parameters and the definition of modes of urban land occupation that translate citizenly values of urban environmental quality.

\section{ACKNOWLEDGEMENTS}

CNPq - Call MCTI/CNPQ/MEC/CAPES No 22/2014, Process: 471089/2014-1, project “Geodesign and Parametric Modeling of Territorial Occupation”. We are especially grateful to the City of Belo Horizonte (Prodabel / PBH) for authorizing the use of data for academic studies.

\section{BIBLIOGRAPHIC REFERENCE}

ANTROP, Marc. Landscape change and the urbanization process in Europe. Landscape and Urban Planning v. 67, n. 1-4, p. 9-26, 2004.

BENEVOLO, L. A cidade e o Arquiteto. São Paulo: Perspectiva, 2004.

BESSA, Kelly Cristina, SOARES, Beatriz Ribeiro. Novas espacialidades urbano-regionais perante a expansão do meio técnico-científico-informacional. Mercator v. 2, n. 4, p. 19-34, 2003.

BRASIL. Estatuto da Cidade: Lei 10.257 de 10 de julho de 2001. 3. ed. Brasília: Câmara dos Deputados, Edições Câmara, 2010.

DUPAGNE, A., HÉGRON, G. Introduction, Architectural and Urban Ambient Environment: First International Workshop, Nantes, France, L'Écoled'Architecture de Nantes, 2002.

FREIRE, N. C. F., PACHECO, A. P. Aspectos da detecção de áreas de risco à desertificação na região de Xingó. XII. Paperpresentedat Simpósio brasileiro de sensoriamento remoto. Anais, INPE, Brasil. 
GIONGO M., KOEHLER, Henrique S., MACHADO, Sebastião do A., KIRCHNER, Flavio F., MARCHETTI, Marco. LiDAR. Pesquisa Florestal Brasileira, Colombo, v.30, n. 63, p. 231-244, 2010.

HOUGHTON, R. A. The Worldwide Extent of Land-use Change. BioScience v. 44, n. 5, p. 305-313 , 1994. Revised June 2015.

LOBODA, Carlos Roberto et al. Áreas Verdes Públicas Urbanas. Revista Ambiência, v. 1, n. 1, 2005.

LYNCH, Kevin. A imagem da cidade, $3^{\text {a }}$ Ed. São Paulo, editora Martins Fontes, 2011.

MASCARÓ, L., MARCARÓ, J. J. Ambiêncie Urbana-UrbanEnvironment. $3^{\text {a }}$ ed. Porto Alegre: Masquatro Editora, 2009.

MOONS, T., 1997. Report on the Joint ISPRS Commission III/IV Workshop "3D Reconstruction and Modelling of Topographic Objects”, Stuttgart, Germany http://www.radig.informatik.tu-muenchen.de/ ISPRS/WG-III4-IV2-Report.html(28 Sep. 1999).

MYNENI, R.B. and Hall, F.G. and Sellers, P.J. and Marshak, A.L. The interpretation of spectral vegetation indexes. IEEE Transactions on Geoscience and Remote Sensing, v.33, p.481-486, 1995.

RAFIEE, A., Dias, E., Koomen, E. Local impact of tree volume on nocturnal urban heat island: A casestudy in Amsterdam. Urban Forestry \& Urban Greening, v.16, p. 50-61, 2016.

RIBAS, Rodrigo P., MOURA, Ana Clara M., CARVALHO, Grazielle A., FONSECA, Bráulio M. Proposição metodológica de extração de altimetria em edificações utilizando dados LiDAR com vista a estudos volumétricos de coeficiente de aproveitamento.SELPER - La Geoinformacion al Servicio de la Sociedad, 2014.

ROUSE, J.W., HAAS, R.H., SCHELL, J.A., DEERING, D.W. "Monitoring vegetation systems in the Great Plains with ERTS". Paper presented at Third Symposium of ERTS, Greenbelt, Maryland, USA. NASA SP-351, V1:309-317.

TOMÁS, Lívia, FONSECA, Leila, ALMEIDA, Cláudia, LEONARDI, Fernando, PEREIRA, Madalena. Urban population estimation based on residential buildings volume using IKONOS-2 images and lidar data, International Journal of Remote Sensing, 37:sup1, 1-28, 2016. DOI: 10.1080/01431161.2015.1121301.

SOUZA, Guilherme H. B., AMORIM, Amilton. LiDAR data integration for 3D Cadastre: some experiences from Brazil. FIG Working Week 2012: Knowing to manage the territory, protect the environment, evaluate the cultural heritage. Rome, Italy, 6-10 May, 2012. 